\title{
Food utilization of two pelagic crustaceans in the Greenland Sea: Meganyctiphanes norvegica (Euphausiacea) and Hymenodora glacialis (Decapoda, Caridea)
}

\author{
Tobias Kreibich ${ }^{1,2}$, Wilhelm Hagen ${ }^{1}$, Reinhard Saborowski ${ }^{2, *}$ \\ ${ }^{1}$ Marine Zoology (FB 2), University of Bremen, PO Box 330440, 28334 Bremen, Germany \\ ${ }^{2}$ Alfred Wegener Institute for Polar and Marine Research, PO Box 120161, 27515 Bremerhaven, Germany
}

\begin{abstract}
Large pelagic crustaceans from Greenland Sea waters, the northern krill Meganyctiphanes norvegica (Euphausiacea) and the decapod shrimp Hymenodora glacialis (Caridea), were captured in depths down to $1500 \mathrm{~m}$ and studied with respect to their physiological food utilization abilities. Both species showed distinct differences in the amount of total lipids (TLs), lipid class and fatty acid (FA) compositions as well as proteolytic enzyme activities. In $M$. norvegica, the overall amount of TLs and storage lipids was much lower than in H. glacialis, and triacylglycerols formed the major lipid fraction with a mean of $48 \%$ TLs. Major FAs comprised the trophic markers 20:1(n-9) and 22:1(n-11), indicating the ingestion of calanid copepods. Additionally, the FAs 22:6(n-3), 18:1(n-9) and 16:0 prevailed. In $H$. glacialis, TLs (mean $=44 \%$ dry mass) were about twice as high as in krill, with wax esters comprising up to $89 \%$ TLs. H. glacialis seems to accumulate these lipids as energy reserves to survive periods of food limitation. Moreover, high lipid levels, particularly wax esters, also help to maintain neutral buoyancy. The major FA in H. glacialis was 18:1(n-9); other dominant FAs were 20:1(n-9) and 22:1(n-11), typical of calanid copepods, as well as the diatom trophic marker 16:1(n-7). Both species showed omnivorous feeding behaviour with a strong tendency towards carnivory. Total proteolytic activities in midgut gland tissue were higher in $M$. norvegica than in H. glacialis. In $M$. norvegica, proteinases were dominated by serine proteinases, whereas cysteine proteinases formed the major group in $H$. glacialis. High proteolytic activity in $M$. norvegica indicates a high digestive potential for proteins and efficient utilization of prey. The presence of different proteinase classes in both species may be due to different group-specific enzyme expression patterns between euphausiids and caridean decapods. Both species follow highly deviating life strategies, as reflected by their specific lipid and enzymatic characteristics.
\end{abstract}

KEY WORDS: Life strategies $\cdot$ Feeding $\cdot$ Lipids $\cdot$ Fatty acids $\cdot$ Trophic markers $\cdot$ Proteinases

\section{INTRODUCTION}

Marine pelagic invertebrates show a variety of ecological and physiological strategies to cope with abiotic and biotic environmental factors such as currents, temperature or food availability. Particularly, high-latitude regions provide challenging conditions for zooplankton species. Productivity of polar and sub-polar regions is restricted to the short summer season. During polar winter, however, phytoplankton production is primarily limited by low light intensity (Codispoti et al. 1991).

Northern krill Meganyctiphanes norvegica (Euphausiacea) appear frequently in the northern and northeastern parts of the Atlantic Ocean. M. norvegica covers a wide distributional area from the Mediterranean to sub-polar waters but is not an explicit Arctic species (Mauchline \& Fischer 1969, Mauchline 1980). Northern krill is able to perform extended diel vertical 
migrations of more than $800 \mathrm{~m}$ as shown in the Mediterranean by Tarling et al. (2001). At night the animals enter the productive surface layers, where they feed on phytoplankton and small zooplankton (Sameoto 1976, 1980, Lass et al. 2001), while they descend to deeper layers during daytime.

Hymenodora glacialis (Oplophoridae) is a genuine deep-water decapod inhabiting Arctic waters (Ritterhoff \& Zauke 1997, Auel \& Hagen 2002) and Northeast Atlantic deep-sea basins (Domanski 1986). Its vertical distribution ranges between 200 and $4100 \mathrm{~m}$. It was classified as truly bathypelagic (Mauchline 1988) and may dominate macrozooplankton biomass in the Arctic deep water (Auel \& Hagen 2002).

Both species co-occur in the Greenland Sea, a region with highly variable seasonal food availability. Strategies to successfully cope with food limitation during the winter may comprise elevated protein catabolism, shrinking of body mass, decrease of metabolic rates or diapausing (Ikeda \& Dixon 1982, Quetin \& Ross 1991, Torres et al. 1994). The efficiency of prey utilization and the ability to accumulate large energy reserves represent other physiological key adaptations to survive unfavourable polar conditions.

We performed a comparative niche-overlapping study between the euphausiid Meganyctiphanes norvegica and the decapod Hymenodora glacialis to investigate their physiological capabilities with regard to lipid storage and alimentary protein utilization. A huge body of literature exists on the biology and life history of $M$. norvegica. In contrast, very little is known
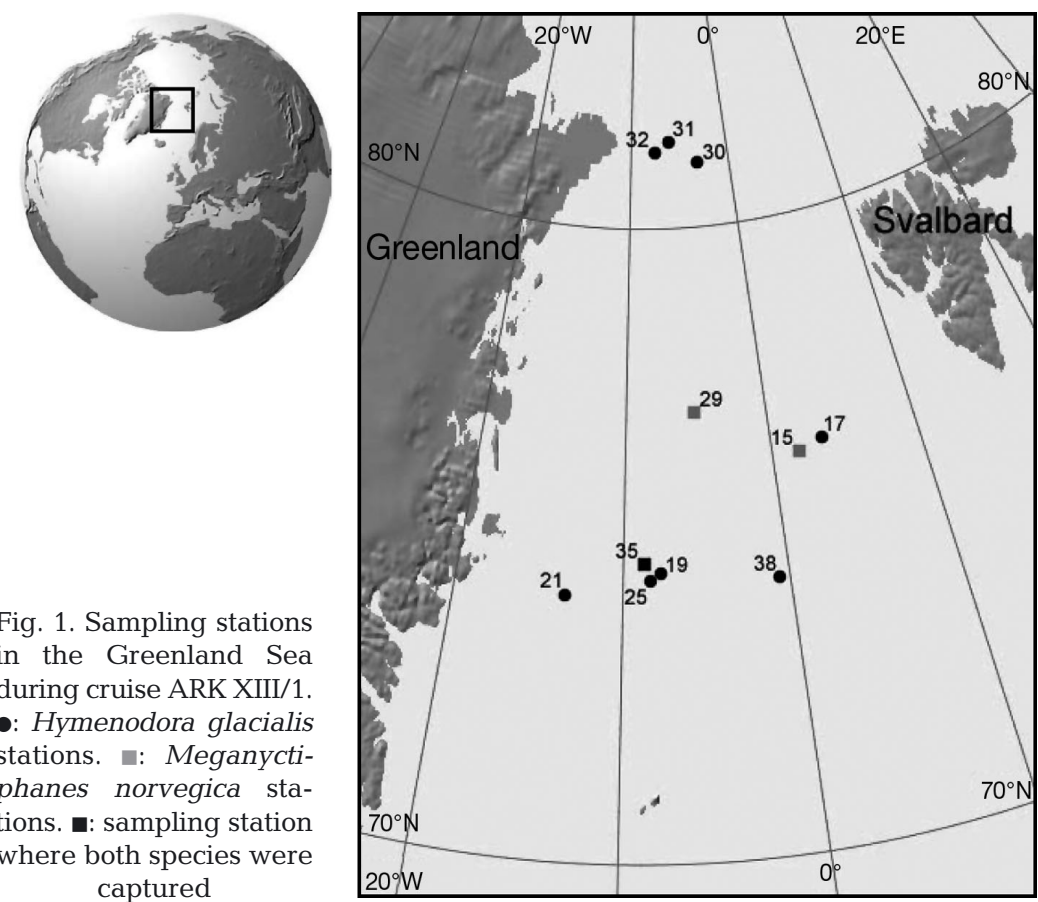

Fig. 1. Sampling stations in the Greenland Sea during cruise ARK XIII/1. -: Hymenodora glacialis stations. -: Meganyctiphanes norvegica stations. 匹: sampling station where both species were captured about the biology and ecophysiology of $H$. glacialis, since this species is much less abundant and therefore not easy to sample. This comparative study aims at elucidating the life strategies and ecophysiological adaptations of $M$. norvegica and $H$. glacialis.

\section{MATERIALS AND METHODS}

Origin of animals. Meganyctiphanes norvegica and Hymenodora glacialis were caught in May-June 1997 during the ARK XIII/1 cruise of RV 'Polarstern' to the Greenland Sea $\left(74^{\circ} 41^{\prime} \mathrm{N}\right.$ to $80^{\circ} 58^{\prime} \mathrm{N}, 13^{\circ} 08^{\prime} \mathrm{W}$ to

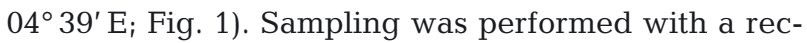
tangular midwater trawl, a bongo net or a multinet (Spindler et al. 1998). Sampling depth ranged from $1500 \mathrm{~m}$ to the surface. Net hauls lasted for $\leq 60 \mathrm{~min}$. Immediately after capture, specimens were briefly rinsed with distilled water, gently blotted dry on filter paper, shock-frozen, and shipped at $-80^{\circ} \mathrm{C}$ to the home laboratories. The biochemical analyses were carried out only on adult individuals with a length of $>30 \mathrm{~mm}$ in the case of $H$. glacialis (Mauchline 1988) and $25 \mathrm{~mm}$ in the case of $M$. norvegica, measured from the eyes to the telson tip (Einarsson 1945, Boysen \& Buchholz 1984). The individuals were in the intermoult stage and ovigerous females were among the samples.

Analysis of total lipid, lipid classes, fatty acids and fatty alcohols. Frozen whole animals were weighed in evacuated glass vials for wet mass determination. Dry mass (DM) was measured after $48 \mathrm{~h}$ of lyophilisation (Leybold-Heraeus, LYOVAC GT2). Lipids were extracted with dichloromethane:methanol (2:1 v/v). The lipid content was determined gravimetrically (Hagen 2000). In order to prevent alterations in lipid composition, lipid extracts were stored at $-80^{\circ} \mathrm{C}$. Lipid classes were separated and analysed after Fraser et al. (1985) by thin-layer chromatography flame ionisation detection (TLC-FID) with an IATROSCAN (Iatron Laboratories, MK-5 TLC/FID Analyser). Fatty acids (FAs) and fatty alcohols were extracted after Kattner \& Fricke (1986) and analysed by gas chromatography (Hewlett Packard, HP 6890 Series) on a wall coated DB-FFAP column (30 $\mathrm{m} \times 0.25 \mathrm{~mm}$ i.d., film thickness $0.25 \mu \mathrm{m}$ ) using a temperature programme (start $165^{\circ} \mathrm{C}, 4^{\circ} \mathrm{C} \mathrm{min}^{-1}$, end $240^{\circ} \mathrm{C}$ for $\left.15 \mathrm{~min}\right)$.

Extracts for enzyme assays. Midgut gland tissue (up to $50 \mathrm{mg}$ ) was dissected from frozen animals, transferred into 
cooled $1.5 \mathrm{ml}$ reaction tubes and weighed. The samples were homogenized in $1 \mathrm{ml}$ of ice-cold demineralised water (aqua dem.). Homogenization was performed with an ultrasonic cell disruptor (Branson, Sonifier Cell Disruptor B15) for $3 \times 5$ s at $30 \%$ of maximum energy, while keeping the samples chilled in an ice-water bath. The homogenates were centrifuged at $15000 \times g\left(4^{\circ} \mathrm{C}\right)$ for $15 \mathrm{~min}$. The supernatants (extracts) were transferred into new reaction tubes, kept on ice and used for subsequent protein and enzyme analyses.

Soluble protein content was quantified after Bradford (1976) using a commercial protein assay (BioRad, 500-0006) and BSA (BioRad, 500-0007) as a standard. The assays were carried out in microplates. Samples were applied in triplicate and standards $(0$ to $5 \mu \mathrm{g}$ well $^{-1}$ ) in duplicate. The optical density of the plates was read after 5 to 15 min of incubation at room temperature with a microplate reader at $600 \mathrm{~nm}\left(\mathrm{OD}_{600}\right)$.

Total proteinase and trypsin activities. Total proteolytic activity was measured with the substrate azocasein. Assays containing $200 \mu \mathrm{l}$ of buffer $\left(0.1 \mathrm{~mol} \mathrm{l}^{-1}\right.$ Tris/ $\mathrm{HCl}$, supplemented with $10 \mathrm{mmol} \mathrm{l}^{-1} \mathrm{CaCl}_{2}$, adjusted to $\mathrm{pH} 6.0$ ) and $20 \mu \mathrm{l}$ of sample were first incubated for $5 \mathrm{~min}$ at $30^{\circ} \mathrm{C}$. Fifty $\mu \mathrm{l}$ azocasein (Fluka $11615,1 \%$ in aqua dem.) were added and incubated for another $30 \mathrm{~min}$ at $30^{\circ} \mathrm{C}$. The reactions were stopped with $500 \mu \mathrm{l}$ trichloroacetic acid (8\% in aqua dem.) and cooling on ice. Controls received $20 \mu$ l of supernatant after the enzymatic reactions were stopped. The reaction cups were centrifuged at $15000 \times g\left(4^{\circ} \mathrm{C}\right)$ for $15 \mathrm{~min}$. The supernatants of samples and controls were measured photometrically at $366 \mathrm{~nm}$.

Tryptic activity was measured with $\mathrm{N}_{\alpha}$-Benzoyl-Larginine-4-nitroanalide-hydrochloride (L-BAPNA) as substrate. Twenty $\mu \mathrm{l}$ of sample were added to $960 \mu \mathrm{l}$ of buffer $\left(0.1 \mathrm{~mol} \mathrm{l} \mathrm{l}^{-1}\right.$ Tris/HCl, supplemented with $10 \mathrm{mmol} \mathrm{l}^{-1} \mathrm{CaCl}_{2}, \mathrm{pH}$ 8.0) and incubated for $5 \mathrm{~min}$ at $30^{\circ} \mathrm{C}$. The trypsin assay was started with $20 \mu \mathrm{l}$ of the substrate L-BAPNA (Fluka, 12915, $50 \mathrm{mmol} \mathrm{l}^{-1}$ ). The reaction was monitored continuously for $180 \mathrm{~s}$ at $405 \mathrm{~nm}$ and $30^{\circ} \mathrm{C}$. The activity was expressed as $U$ per $\mathrm{g}$ fresh mass $\left(\mathrm{g}_{\mathrm{FM}}{ }^{-1}\right)\left(=\mu \mathrm{mol} \mathrm{min}^{-1} \mathrm{~g}_{\mathrm{FM}}{ }^{-1}\right)$.

Inhibitor studies. Inhibitor assays were carried out as reported by Teschke \& Saborowski (2005). Serine proteinase (EC 3.4.21) were inhibited with AEBSF (4[2-Aminoethyl] benzenesulfonyl fluoride hydrochloride; Merck, Pefabloc ${ }^{\circledR}$ SC) and cysteine proteinase (EC 3.4.22) with E-64 (trans-Epoxysuccinyl-L-leucylamido[4-guanidino]butane; Sigma, E 3132). Midgut gland extracts $(20 \mu \mathrm{l})$ were incubated at $25^{\circ} \mathrm{C}$ with $20 \mu \mathrm{l}$ of aqueous solutions of inhibitors $\left(1 \mathrm{mmol}^{-1}\right)$. After $60 \mathrm{~min}, 180 \mu \mathrm{l}$ of Tris-HCl buffer $\left(0.1 \mathrm{~mol} \mathrm{l}^{-1}\right.$, $10 \mathrm{mmol} \mathrm{l}^{-1} \mathrm{CaCl}_{2}, \mathrm{pH}$ 6.0) were added and incubation was continued as described above for the assay of total proteinase. The remaining activity was calculated in relation to a control, which received water but no inhibitors.

Statistics. Statistical analyses were performed with the computer programme SigmaStat (SPSS, Version 2.03). Normal distributions and homogeneity of variances were determined with the Kolmogorov-Smirnov and Levine median tests, respectively. Data sets were compared with a $t$-test, a 1-way ANOVA (data normally distributed) or a Whitney-Mann rank sum test (data not normally distributed). Post-hoc tests consisted of Dunn's or Tukey's tests, respectively. The $\alpha$-value was set at 0.05 . Data in figures and tables are means $\pm \mathrm{SD}$.

Similarity analysis of FA data sets was performed with Primer 5 (Primer-E, Version 5.2.9). The data sets consisted of the relative amounts (\%) of the FAs in relation to total lipids. Only major fatty acids ( $\geq 1 \%$ of total fatty acids, TFAs) were considered. The data were arcsin square root-transformed and subjected to a BrayCurtis similarity analysis. The result of the similarity analysis is presented as a dendrogram using the complete-linkage procedure.

\section{RESULTS}

\section{Morphometric data}

Adult specimens of Meganyctiphanes norvegica which were selected for biochemical analysis ranged in size from 25 to $44 \mathrm{~mm}$. Hymenodora glacialis specimens ranged from 30 to $82 \mathrm{~mm}$. The details of morphometric data are listed in (Table 1).

\section{Total lipids and lipid classes}

The total lipid concentration was significantly lower in Meganyctiphanes norvegica than in Hymenodora glacialis (Table 2). In M. norvegica, triacylglycerols formed the major portion of total lipids. Conversely, wax esters were the dominant storage lipids in $H$. glacialis, while the concentration of triacylglycerols was low. Free fatty acids appeared in low amounts in both species, indicating a low degree of autolysis of the samples. The amounts of sterols as well as phospholipids were significantly higher in $M$. norvegica than in H. glacialis.

In Meganyctiphanes norvegica the triacylglycerol content was positively correlated with total lipid content (Fig. 2a). Conversely, in Hymenodora glacialis the amount of wax esters was positively correlated with the overall amount of lipids, while no correlation was found between triacylglycerols and total lipids (Fig. 2b). In both species, phospholipids (\% DM) re- 
Table 1. Meganyctiphanes norvegica and Hymenodora glacialis. Morphometric details of analysed specimens. M: male; F: female; Lip: lipid analysis; Enz: enzyme assay; nd: not determined

\begin{tabular}{|c|c|c|c|c|c|c|}
\hline $\begin{array}{l}\text { Species } \\
\text { and ID }\end{array}$ & $\begin{array}{l}\text { Sampling } \\
\text { station }\end{array}$ & $\begin{array}{l}\text { Total length } \\
(\mathrm{mm})\end{array}$ & $\begin{array}{l}\text { Fresh mass } \\
\quad(\mathrm{mg})\end{array}$ & $\begin{array}{l}\text { Dry mass } \\
(\mathrm{mg})\end{array}$ & Sex & Analysis \\
\hline \multicolumn{7}{|c|}{ Meganyctiphanes norvegica } \\
\hline $\mathrm{Mn}-15 / 1$ & 15 & 32 & nd & 16.87 & $\mathrm{M}$ & Lip \\
\hline Mn-15/2 & 15 & 35 & nd & 24.45 & $\mathrm{~F}$ & Lip \\
\hline Mn-29/1 & 29 & 37 & nd & 22.36 & $\mathrm{~F}$ & Lip \\
\hline Mn-29/2 & 29 & 37 & nd & 27.57 & $\mathrm{~F}$ & Lip \\
\hline Mn-15/3 & 15 & 38 & nd & 40.01 & $\mathrm{M}$ & Lip \\
\hline Mn-15/4 & 15 & 40 & nd & 49.62 & $\mathrm{~F}$ & Lip \\
\hline Mn-29/3 & 29 & 42 & nd & 26.98 & $\mathrm{~F}$ & Lip \\
\hline Mn-29/4 & 29 & 42 & nd & 33.11 & $\mathrm{~F}$ & Lip \\
\hline Mn-15/5 & 15 & 42 & nd & 39.27 & $\mathrm{M}$ & Lip \\
\hline Mn-29/5 & 29 & 44 & nd & 22.75 & $\mathrm{M}$ & Lip \\
\hline Mn-32/1 & 32 & 37 & nd & nd & $\mathrm{F}$ & Enz \\
\hline Mn-32/2 & 35 & 39 & nd & nd & $\mathrm{M}$ & Enz \\
\hline $\mathrm{Mn}-32 / 3$ & 35 & 27 & nd & nd & W & Enz \\
\hline Mn-29/6 & 29 & 38 & nd & nd & $\mathrm{M}$ & Enz \\
\hline Mn-29/7 & 29 & 39 & nd & nd & $\mathrm{F}$ & Enz \\
\hline Mn-29/8 & 29 & 25 & nd & nd & $\mathrm{M}$ & Enz \\
\hline Mn-29/9 & 29 & 33 & nd & nd & $\mathrm{M}$ & Enz \\
\hline Mn-29/10 & 29 & 40 & nd & nd & $\mathrm{F}$ & Enz \\
\hline Mn-29/11 & 29 & 36 & nd & nd & $\mathrm{M}$ & Enz \\
\hline \multirow{3}{*}{\multicolumn{2}{|c|}{$\begin{array}{l}\text { Mean } \pm \text { SD } \\
\text { Range (min.-max.) } \\
\text { N }\end{array}$}} & $37.0 \pm 4.96$ & nd & $30.3 \pm 10.1$ & & \\
\hline & & $25-44$ & nd & $16.87-49.62$ & & \\
\hline & & 19 & nd & 10 & & \\
\hline \multicolumn{7}{|c|}{ Hymenodora glacialis } \\
\hline $\mathrm{Hg}-17 / 1$ & 17 & 35 & 355.5 & 57.2 & nd & Lip \\
\hline $\mathrm{Hg}-31 / 1$ & 31 & 35 & 946.1 & 177.1 & nd & Lip \\
\hline $\mathrm{Hg}-32 / 1$ & 32 & 35 & 412.9 & 77.3 & nd & Lip \\
\hline $\mathrm{Hg}-25 / 1$ & 25 & 37 & 511.9 & 141.7 & nd & Lip \\
\hline $\mathrm{Hg}-38 / 1$ & 38 & 37 & 437.9 & 93.8 & nd & Lip \\
\hline $\mathrm{Hg}-25 / 2$ & 25 & 39 & 687.9 & 165.4 & nd & Lip \\
\hline $\mathrm{Hg}-21 / 1$ & 21 & 40 & 544 & 148.7 & nd & Lip \\
\hline $\mathrm{Hg}-35 / 1$ & 35 & 40 & 1251.2 & 264.9 & nd & Lip \\
\hline $\mathrm{Hg}-30 / 1$ & 30 & 45 & 826.7 & 169.1 & nd & Lip \\
\hline $\mathrm{Hg}-38 / 2$ & 38 & 45 & 1518.7 & 369.2 & nd & Lip \\
\hline $\mathrm{Hg}-32 / 2$ & 32 & 47 & 918.6 & 100.3 & nd & Lip \\
\hline $\mathrm{Hg}-25 / 3$ & 25 & 49 & 1142.1 & 208.9 & nd & Lip \\
\hline $\mathrm{Hg}-38 / 3$ & 38 & 50 & 1491.7 & 485.6 & nd & Lip \\
\hline $\mathrm{Hg}-25 / 4$ & 25 & 50 & 994.4 & 162.4 & nd & Lip \\
\hline $\mathrm{Hg}-19 / 1$ & 19 & 52 & 1218.2 & 248.3 & nd & Lip \\
\hline $\mathrm{Hg}-32 / 3$ & 32 & 52 & 1176.9 & 242.8 & nd & Lip \\
\hline $\mathrm{Hg}-25 / 5$ & 25 & 70 & 3317.4 & 896.1 & nd & Lip \\
\hline $\mathrm{Hg}-21 / 2$ & 21 & 82 & 4445.2 & 1056.6 & nd & Lip \\
\hline $\mathrm{Hg}-31 / 2$ & 31 & 34 & nd & nd & nd & Enz \\
\hline $\mathrm{Hg}-32 / 4$ & 32 & 36 & nd & nd & nd & Enz \\
\hline $\mathrm{Hg}-32 / 5$ & 32 & 37 & nd & nd & nd & Enz \\
\hline $\mathrm{Hg}-32 / 6$ & 32 & 38 & nd & nd & nd & Enz \\
\hline $\mathrm{Hg}-32 / 7$ & 32 & 39 & nd & nd & nd & Enz \\
\hline $\mathrm{Hg}-32 / 8$ & 32 & 40 & nd & nd & nd & Enz \\
\hline $\mathrm{Hg}-25 / 6$ & 25 & 41 & nd & nd & nd & Enz \\
\hline $\mathrm{Hg}-32 / 9$ & 32 & 44 & nd & nd & nd & Enz \\
\hline $\mathrm{Hg}-25 / 7$ & 25 & 46 & nd & nd & nd & Enz \\
\hline $\mathrm{Hg}-32 / 10$ & 32 & 46 & nd & nd & nd & Enz \\
\hline $\mathrm{Hg}-32 / 11$ & 32 & 47 & nd & nd & nd & Enz \\
\hline $\mathrm{Hg}-32 / 12$ & 32 & 47 & nd & nd & nd & Enz \\
\hline $\mathrm{Hg}-32 / 13$ & 32 & 48 & nd & nd & nd & Enz \\
\hline $\mathrm{Hg}-32 / 14$ & 32 & 48 & nd & nd & nd & Enz \\
\hline $\mathrm{Hg}-35 / 2$ & 35 & 49 & nd & nd & nd & Enz \\
\hline $\mathrm{Hg}-25 / 8$ & 25 & 53 & nd & nd & nd & Enz \\
\hline $\mathrm{Hg}-25 / 9$ & 25 & 57 & nd & nd & nd & Enz \\
\hline $\mathrm{Hg}-25 / 10$ & 25 & 57 & nd & nd & nd & Enz \\
\hline $\mathrm{Hg}-19 / 2$ & 19 & 59 & nd & nd & nd & Enz \\
\hline $\mathrm{Hg}-35 / 3$ & 35 & 62 & nd & nd & nd & Enz \\
\hline $\mathrm{Hg}-38 / 4$ & 38 & 70 & nd & nd & nd & Enz \\
\hline \multirow{3}{*}{\multicolumn{2}{|c|}{$\begin{array}{l}\text { Mean } \pm \text { SD } \\
\text { Range (min.-max.) } \\
\text { N }\end{array}$}} & $47.1 \pm 10.8$ & $1233 \pm 1046$ & \multicolumn{3}{|l|}{$281.4 \pm 274.9$} \\
\hline & & $34-82$ & $355.5-4445.2$ & \multirow{2}{*}{\multicolumn{3}{|c|}{$\begin{array}{c}57.2-1056.6 \\
18\end{array}$}} \\
\hline & & 39 & 18 & & & \\
\hline
\end{tabular}

mained at constant levels irrespective of the amount of total lipids.

\section{Fatty acids and fatty alcohols}

Only the major FAs ( $>1 \%$ of TFAs) were considered for the interspecific comparison (Fig. 3). The share of the saturated fatty acids (SFAs) 14:0 and 16:0 differed significantly between Meganyctiphanes norvegica and Hymenodora glacialis, while 18:0 showed no differences. The amount of the monounsaturated fatty acids (MUFAs) 16:1(n-7), 18:1(n-9) and 22:1(n-9) were lower in $M$. norvegica than in $H$. glacialis. In contrast, the MUFA 18:1(n-7) did not differ significantly between species ( $3.6 \%$ TFAs), nor did the long-chain FA 22:1(n-11) ( 12\% TFAs). Three polyunsaturated fatty acids (PUFAs), 18:4(n-3), 20:5(n-3) and 22:6(n-3), were identified (Fig. 3). Each of these PUFAs showed significant differences between species.

No fatty alcohols were identified in Meganyctiphanes norvegica, while various fatty alcohols were present in $\mathrm{Hy}$ menodora glacialis (Table 3). The major fatty alcohol was 22:1(n-11), which accounted for $>40 \%$ of total fatty alcohols. The monounsaturated fatty alcohol $18: 1(n-9)$ showed values of $\sim 25.0 \%$, but with the highest variability. The major saturated fatty alcohol was 16:0.

Data sets of the relative FA composition of individuals of both species were subjected to a similarity analysis. The resulting dendrogram displays distinct species-specific clusters, clearly separating Meganyctiphanes norvegica from Hymenodora glacialis at a similarity level of $62 \%$ (Fig. 4 ).

\section{Enzyme activities}

In Meganyctiphanes norvegica, the average total proteolytic activity amounted to $57.4 \pm 27.1 \Delta \mathrm{E}_{366}$ (photometric extinction at $366 \mathrm{~nm}$ ) $\mathrm{min}^{-1} \mathrm{~g}_{\mathrm{FM}}{ }^{-1}$ (Fig. 5a). In Hymenodora glacialis, total proteolytic activities were $<5 \%$ of that in $M$. norvegica, at $2.4 \pm 2.3 \Delta \mathrm{E}_{366} \mathrm{~min}^{-1} \mathrm{~g}_{\mathrm{FM}}{ }^{-1}$ (Fig. 5a). Trypsin activity was highest in 
Table 2. Meganyctiphanes norvegica and Hymenodora glacialis. Total lipid content (mg, mean $\pm \mathrm{SD}$, range in parentheses) and composition of lipid classes (\% dry mass [DM], \% total lipids [TL]) of $M$. norvegica $(\mathrm{n}=10)$ and $H$. glacialis $(\mathrm{n}=$ 18). Significance levels were calculated with a Mann-Whitney rank sum test ${ }^{\mathrm{a}}$ or a $t$-test ${ }^{\mathrm{b}}$. nd: not determined; ns: not significant; ${ }^{*} \mathrm{p}<0.05_{;}{ }^{* *} \mathrm{p}<0.01_{;}{ }^{* * *} \mathrm{p}<0.001$

\begin{tabular}{|c|c|c|c|c|}
\hline Lipid content/composition & Units & M. norvegica & H. glacialis & Significance \\
\hline Total lipids & $\mathrm{mg}$ & $\begin{array}{l}15.1 \pm 5.0 \\
(8.4-24.8)\end{array}$ & $\begin{array}{c}83.6 \pm 127.8 \\
(2.0-474.7)\end{array}$ & $* * * a$ \\
\hline Neutral lipids & $\% \mathrm{DM}$ & $27.6 \pm 5.2$ & $43.9 \pm 14.2$ & $* * * a$ \\
\hline Wax esters & $\begin{array}{l}\% \mathrm{DM} \\
\% \mathrm{TL}\end{array}$ & $\begin{array}{l}1.6 \pm 0.6 \\
6.0 \pm 3.1\end{array}$ & $\begin{array}{l}38.8 \pm 13.6 \\
88.6 \pm 10.2\end{array}$ & $\begin{array}{l}* * * \mathrm{~b} \\
* * \mathrm{a}\end{array}$ \\
\hline Triacylglycerols & $\begin{array}{l}\% \mathrm{DM} \\
\% \mathrm{TL}\end{array}$ & $\begin{array}{l}17.5 \pm 5.3 \\
62.2 \pm 9.6\end{array}$ & $\begin{array}{l}3.1 \pm 4.9 \\
6.8 \pm 9.9\end{array}$ & $\begin{array}{l}* * * \mathrm{~b} \\
* * * \mathrm{~b}\end{array}$ \\
\hline Free fatty acids & $\begin{array}{l}\% \mathrm{DM} \\
\% \mathrm{TL}\end{array}$ & $\begin{array}{c}0.04 \pm 0.1 \\
0.1 \pm 0.3\end{array}$ & $\begin{array}{l}0.02 \pm 0.07 \\
0.02 \pm 0.11\end{array}$ & $\begin{array}{l}\mathrm{ns} \\
\mathrm{ns}\end{array}$ \\
\hline Sterols & $\begin{array}{l}\% \mathrm{DM} \\
\% \mathrm{TL}\end{array}$ & $\begin{array}{l}0.4 \pm 0.2 \\
1.6 \pm 0.8\end{array}$ & $\begin{array}{l}0.2 \pm 0.2 \\
0.5 \pm 0.3\end{array}$ & $\begin{array}{l}* * * \mathrm{~b} \\
* * * \mathrm{~b}\end{array}$ \\
\hline $\begin{array}{l}\text { Membrane lipids } \\
\text { Phospholipids }\end{array}$ & $\begin{array}{l}\% \mathrm{DM} \\
\% \mathrm{TL}\end{array}$ & $\begin{array}{c}7.7 \pm 1.2 \\
29.1 \pm 7.6\end{array}$ & $\begin{array}{l}1.7 \pm 1.3 \\
4.1 \pm 2.5\end{array}$ & $\begin{array}{l}* * * \mathrm{~b} \\
* * * \mathrm{~b}\end{array}$ \\
\hline Unknown lipids & $\begin{array}{l}\% \mathrm{DM} \\
\% \mathrm{TL}\end{array}$ & $\begin{array}{l}0.3 \pm 0.4 \\
1.1 \pm 1.1\end{array}$ & $\begin{array}{l}\text { nd } \\
\text { nd }\end{array}$ & \\
\hline
\end{tabular}

M. norvegica as well, reaching $7.3 \pm 2.6$ $\mathrm{U} \mathrm{g}_{\mathrm{FM}}{ }^{-1}$ (Fig. 5b). H. glacialis showed much lower trypsin activities $(0.32 \pm 0.16$ $\mathrm{U}_{\mathrm{FM}}{ }^{-1}$ ) than $M$. norvegica.

\section{Inhibition assays}

In Meganyctiphanes norvegica, the cysteine proteinase inhibitor E-64 lowered proteolytic activity to $76.1 \%$ of initial values (Fig. 6). The specific serine proteinase inhibitor AEBSF caused a significantly higher degree of inhibition to $44.9 \%$ of the initial value $(\mathrm{p}=0.006)$. In Hymenodora glacialis, a significantly higher inhibition of proteinase activity was obtained with E-64 than with AEBSF $(p<0.001)$. The residual proteolytic activity amounted to $12.0 \%$ of the uninhibited values after E-64 treatment. In contrast, residual activity remained at $93.8 \%$ after applying AEBSF.

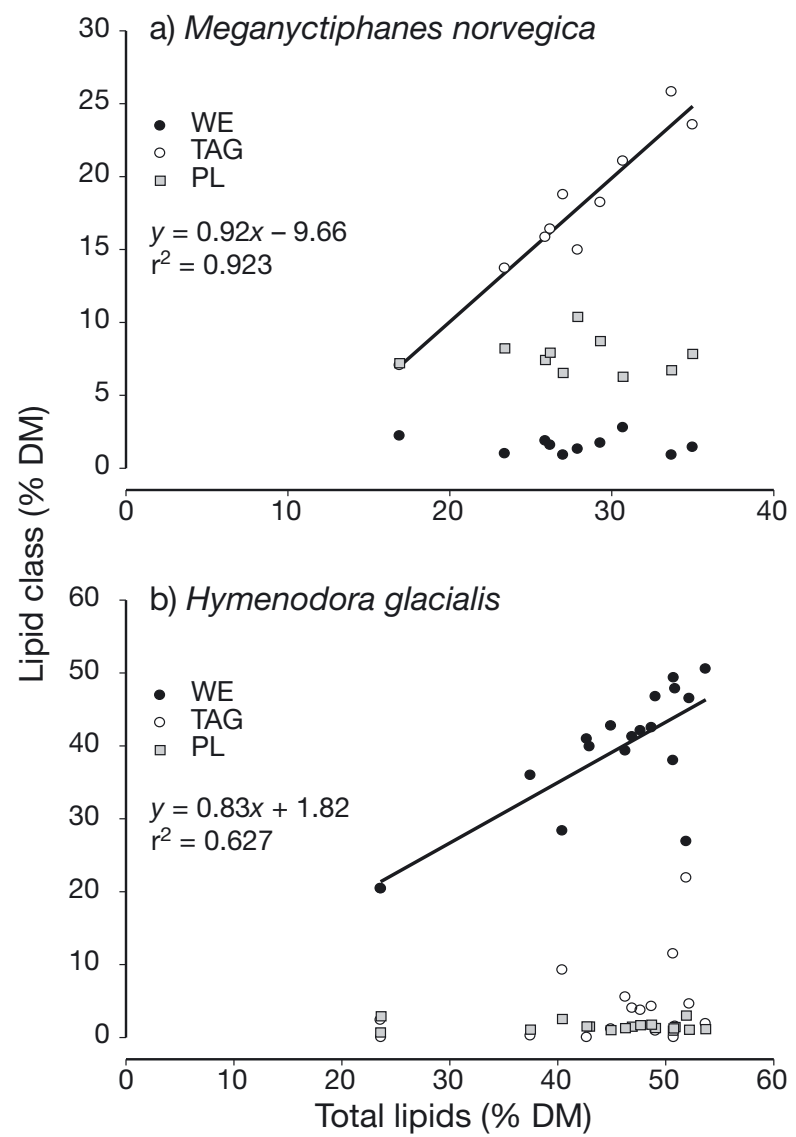

Fig. 2. Correlation between wax esters (WE), triacylglycerols (TAG), phospholipids (PL) and the amount of total lipid in \% dry mass (DM) for (a) Meganyctiphanes norvegica $(\mathrm{n}=10)$ and (b) Hymenodora glacialis $(\mathrm{n}=18)$. Note different scaling

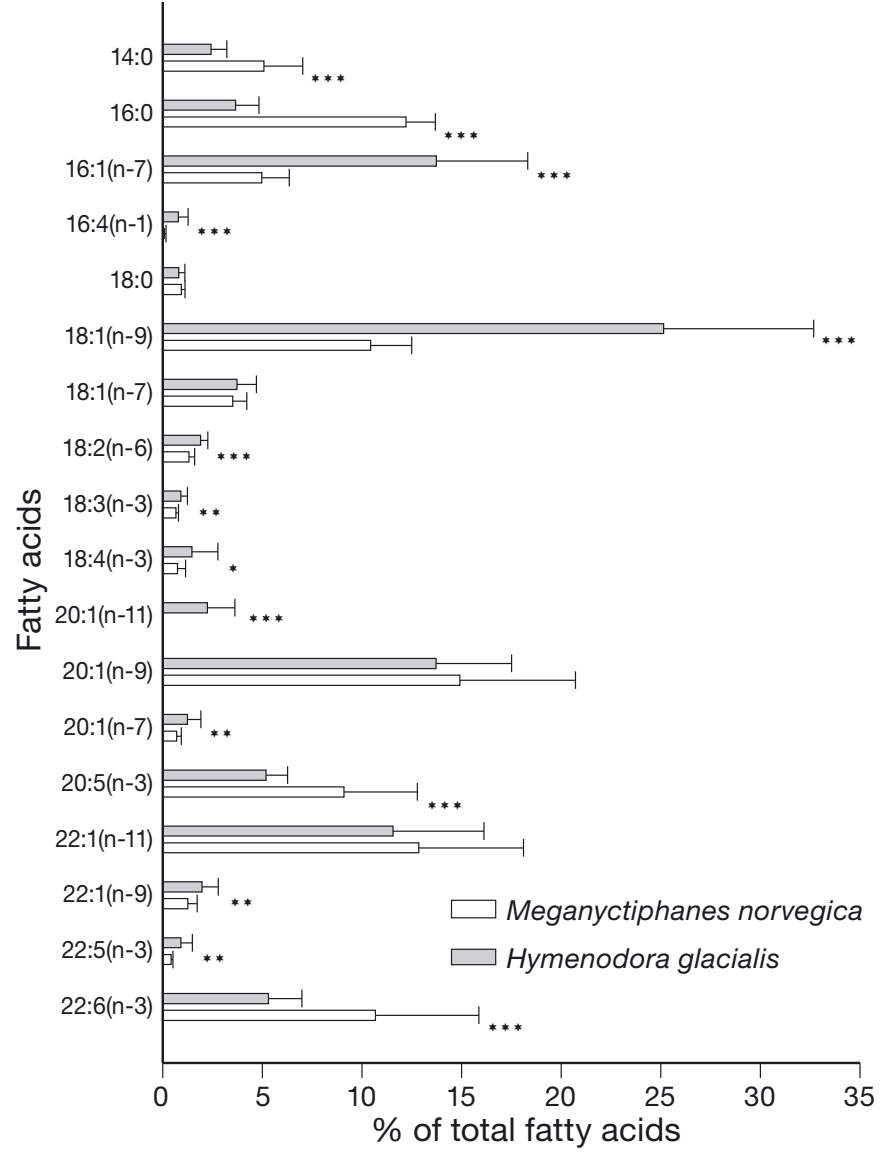

Fig. 3. Selected fatty acids ( $>1 \%$ of total fatty acids, means \pm $\mathrm{SD})$, of Meganyctiphanes norvegica $(\mathrm{n}=10)$ and Hymenodora glacialis $(\mathrm{n}=18)$. ${ }^{*} \mathrm{p}<0.05{ }^{*}{ }^{* *} \mathrm{p}<0.01 ;{ }^{* * *} \mathrm{p}<0.001$ 
Table 3. Hymenodora glacialis. Major fatty alcohols in \% of total fatty alcohols (mean $\pm \mathrm{SD}, \mathrm{n}=18$ )

\begin{tabular}{|cc|}
\hline Fatty alcohol & \% of total alcohols \\
\hline $14: 0$ & $3.1 \pm 1.8$ \\
$16: 0$ & $9.6 \pm 3.3$ \\
$18: 0$ & $1.1 \pm 0.4$ \\
$18: 1(\mathrm{n}-7)$ & $2.2 \pm 1.5$ \\
$18: 1(\mathrm{n}-9)$ & $10.6 \pm 11.7$ \\
$20: 1(\mathrm{n}-7)$ & $0.9 \pm 1.3$ \\
$20: 1(\mathrm{n}-9)$ & $25 \pm 2.4$ \\
$22: 1(\mathrm{n}-9)$ & $5.2 \pm 3.2$ \\
$22: 1(\mathrm{n}-11)$ & $42.2 \pm 13.5$ \\
\hline
\end{tabular}

\section{DISCUSSION}

Meganyctiphanes norvegica and Hymenodora glacialis showed distinct differences in the quantity and quality of storage lipids, FA composition, proteolytic enzyme activity and expression of proteinase classes. These results clearly indicate that, at least during the sampling period, both crustacean species followed very different physiological traits of food utilization and energy storage.

\section{Feeding ecology}

A huge body of literature exists on the feeding ecology of Meganyctiphanes norvegica. Different zooplankton and phytoplankton species have been identified as major food items (e.g. Mauchline 1980, Sameoto 1980, McClatchie 1985, Lass et al. 2001). Although prey preference varies strongly with season and location
(Lass et al. 2001), the feeding mode of northern krill has been classified as opportunistic and non-selective (Mauchline 1980, Buchholz et al. 1995, Lass et al. 2001). However, Kaartvedt et al. (2002) suggested that carnivorous feeding is performed selectively by visually hunting zooplankton, e.g. various copepod species. Northern krill perform extended and energy-demanding diurnal vertical migrations which are associated with feeding activities at the surface during darkness, whereas during the daytime krill stay at depth and feed on zooplankton such as copepods (Sameoto 1980, Tarling et al. 1999, Kaartvedt et al. 2002).

In contrast, information about the vertical distribution and feeding preferences of Hymenodora glacialis is limited. Mauchline (1988) categorized these decapods as bathypelagic non-migrators. $H$. glacialis specimens were mostly caught below 1000 m (Domanski 1986, Ritterhoff \& Zauke 1997, Auel \& Hagen 2002), while they were rarely observed in epipelagic waters (Wishner 1980, Mauchline 1988). In Arctic deep waters, Calanus hyperboreus represents one of the dominant copepod species. Depending on the season, adults as well as juvenile stages occur frequently between the surface and $3000 \mathrm{~m}$ depth (Head \& Conover 1983, Hirche 1989, 1997, Richter 1995, Hirche \& Niehoff 1996). Thus C. hyperboreus may provide a major food source for $H$. glacialis, especially in winter, when Calanus species descend to deeper waters. Stomach content analyses of $H$. glacialis by Domanski (1986) revealed parts of small crustaceans, chaetognaths and undefined gelatinous matter, which also support the notion of carnivorous feeding preferences. In contrast, there is no indication of herbivory for $H$. glacialis from the literature.

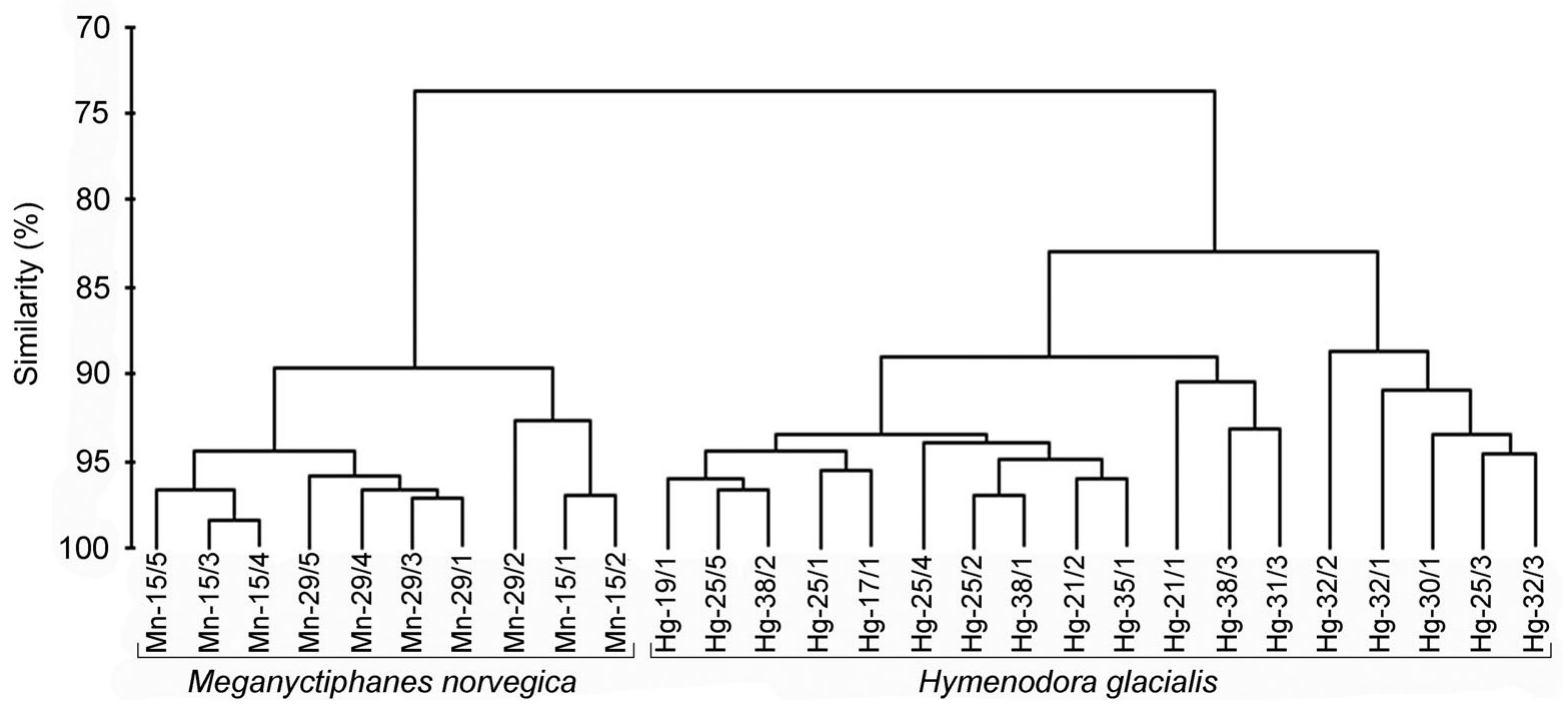

Fig. 4. Dendrogram of Bray-Curtis similarities between the fatty acid patterns of individual Meganyctiphanes norvegica and Hymenodora glacialis 

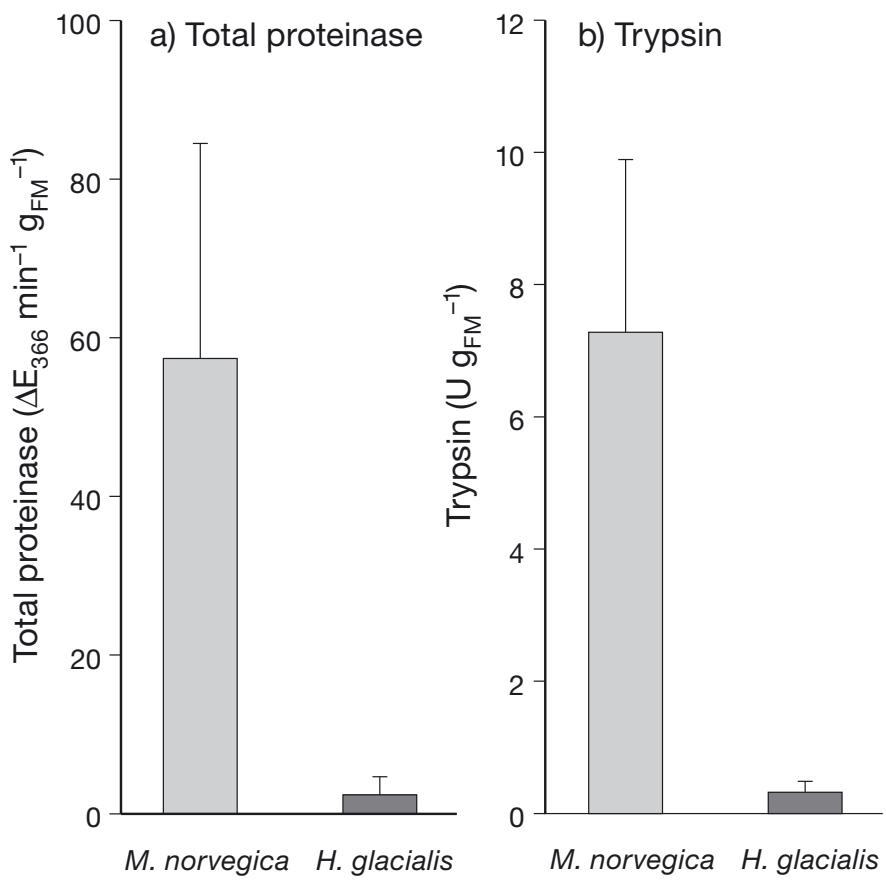

Fig. 5. Activities of (a) total proteinase and (b) trypsin in the midgut glands of Meganyctiphanes norvegica and Hymenodora glacialis at optimum $\mathrm{pH}$ (means $\pm \mathrm{SD}, \mathrm{n}=4$ to 21). Both activities were significantly higher in $M$. norvegica than in H. glacialis $(\mathrm{p}=0.001) . \Delta \mathrm{E}_{366}$ : photometric extinction at $366 \mathrm{~nm}$; $\mathrm{g}_{\mathrm{FM}}: \mathrm{g}$ fresh mass

\section{Lipids}

Both species are strongly influenced by the pronounced seasonal changes of productivity in sub-arctic waters. However, the amount of total lipids in relation to dry mass was twice as high in Hymenodora glacialis as compared to Meganyctiphanes norvegica.

The total lipid content in Meganyctiphanes norvegica may range from $<25 \%$ DM in late spring and early summer to $>50 \%$ DM in winter (Sargent \& FalkPetersen 1981, Saether et al. 1986, Falk-Petersen et al. 2000, W. Hagen unpubl. data). In our samples from May-June, lipid contents averaged $22.1 \pm 9.4 \% \mathrm{DM}$, which indicates that krill were passing through the period of low lipid levels. According to Falk-Petersen et al. (2000), M. norvegica mobilizes storage lipids during winter and spring resulting in lipid levels of $<20 \%$ DM during summer. Lipid accumulation takes place mainly during the following autumn. Reproduction does not seem to influence lipid dynamics, since $M$. norvegica does not spawn in Arctic waters (Einarsson 1945). Triacylglycerols formed the major fraction of neutral lipids in M. norvegica, while the amount of wax esters was rather low. Triacylglycerols are known as short-term depot lipids which are used to meet metabolic energy requirements (Mayzaud et al. 1998, Lee

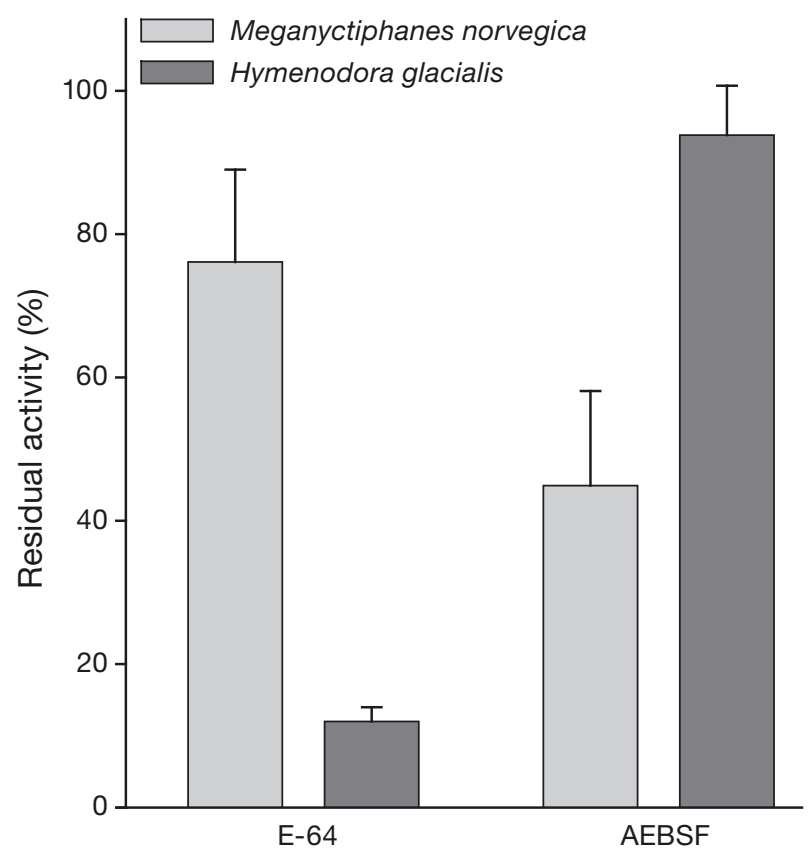

Fig. 6. Residual activities (relative values) after inhibition of total proteinase with the cysteine proteinase inhibitor E-64 and the serine proteinase inhibitor AEBSF in midgut gland extracts of Meganyctiphanes norvegica and Hymenodora glacialis ( $\mathrm{n}=3$ to 5 ). Inhibition with E-64 was significantly stronger in $H$. glacialis than in $M$. norvegica $(p<0.001)$

et al. 2006). Their function as a major energy store in M. norvegica may be related to a rapid lipid turnover, possibly due to an active mode of life year-round, which thus may entail a more or less continuous food uptake throughout all seasons (Sargent et al. 1981). The traces of wax esters in the samples originate most likely from freshly ingested and thus incompletely digested prey rich in wax esters, e.g. calanid copepods (Calanus spp.).

The lipid content of Hymenodora glacialis averaged $44 \%$ DM. Unfortunately, limited data were available on the seasonal lipid dynamics of this species. However, in catches from other seasons the average lipid content amounted to $46 \%$ DM in April (ARK IX) and 35 to $40 \%$ DM in August (ARK VII) (W. Hagen unpubl. data). In other pelagic crustaceans this level may represent the seasonal lipid maximum (Falk-Petersen et al. 2000). Accordingly, H. glacialis seems less affected by seasonal fluctuations of internal lipid stores than Meganyctiphanes norvegica. In contrast to northern krill, H. glacialis predominantly accumulated wax esters, which reached almost $90 \%$ of total lipids. Wax esters are major storage products in many high-latitude zooplankton species (Lee et al. 2006). They are suggested to be more suitable for rapid accumulation of large lipid stores (Sargent et al. 1974) and they can 
be deposited in the body for extended periods, e.g. for up to 8 mo in adult Acanthephyra pelagica (Opliphoridae) (Clarke \& Holmes 1986). As suggested by Hagen et al. (1993) from studies on 2 sympatric primarily herbivorous copepod species from Antarctic waters, the deposition of wax esters may be related to discontinuous seasonal feeding, while triacylglycerol accumulation may reflect continuous seasonal food uptake. The carnivorous wax ester-rich $H$. glacialis, however, appears to exhibit continuous feeding throughout the year, since no pronounced fluctuations of the lipid depots were obvious from the existing data, characteristics similar to the carnivorous Antarctic copepod Paraeuchaeta antarctica, which also stores wax esters (Hagen et al. 1995). The accumulation of wax esters reflects the chemical composition of preferred prey species, among them C. hyperboreus, which are rich in wax esters with long-chain MUFAs and fatty alcohols (Kattner \& Hagen 1995). However, it remains to be investigated whether or not $H$. glacialis are capable of synthesising wax esters themselves. Wax esters may also play an important role in reproductive processes (Hagen \& Kattner 1998) and they prevail in the large lipid-rich eggs of $H$. glacialis (W. Hagen unpubl. data). H. glacialis have no distinct spawning period but breed continuously throughout the year (Mauchline 1988). Accordingly, they depend on a continuous food supply, which again is in accordance with low seasonal fluctuations of somatic lipid stores.

Another major advantage of high lipid and wax ester levels may be their function as buoyancy aids. Among the dominant neutral lipid classes, wax esters provide the strongest uplift (Yayanos et al. 1978), which may be quite advantageous for the rather large and heavy Hymenodora glacialis in saving metabolic energy.

\section{Fatty acids and fatty alcohols}

FAs, which typically appear in specific prey organisms, can serve as suitable tracers or biomarkers for trophic interactions (e.g. Sargent \& Whittle 1981, Graeve et al. 1994, Dalsgaard et al. 2003). In our samples the FA composition of Meganyctiphanes norvegica confirms their omnivorous but predominantly carnivorous feeding behaviour. On the one hand, the unsaturated FAs 20:1(n-9) and 22:1(n-11) contributes the highest shares to total FAs. These long-chain MUFAs are typical of wax esters originating from Calanus species (Kattner \& Hagen 1995, Dalsgaard et al. 2003). Other FAs or the ratios between certain FAs such as 20:5(n-3) to 22:6(n-3) indicate omnivory with a strong tendency to carnivory as well (Ackman et al. 1970). On the other hand, the FAs 16:1(n-7) and 18:4(n-3) are typical for diatoms and dinoflagellates, respectively. In
M. norvegica they are present at levels of only 5.0 and $0.7 \%$. The ratio of $8: 1$ between $16: 1(n-7)$ and $18: 4(n-3)$ indicates a higher share of diatoms than dinoflagellates in the food (Stübing \& Hagen 2003), although these phytoplankton markers may have been ingested with herbivorous calanid copepods.

The present study provides first information on the lipid and FA composition of Hymenodora glacialis. The highest share of $25 \%$ of total FA was contributed by 18:1(n-9), which may form a significant component of storage lipids (Stübing \& Hagen 2003) and has been suggested as an indicator of carnivory (Falk-Petersen et al. 1990). The Calanus markers 20:1(n-9) and 22:1 (n-11) also showed high values of 13.7 and $11.6 \%$ TFAs, respectively, suggesting that $H$. glacialis feed on calanid copepods as a major food source. Accordingly, the fatty alcohols of $H$. glacialis were dominated by 20:1(n-9) and 22:1(n-11). These fatty alcohols certainly originate from ingested wax esters of calanid copepods, which are able to synthesize these monounsaturated lipid moieties de novo (Lee 1974, Kattner et al. 1989, Kattner \& Graeve 1991, Lee et al. 2006). The FA 16:1(n-7) in H. glacialis indicates the presence of diatoms. Diatoms often dominate phytoplankton stock in the Greenland Sea. However, there is no indication that bathypelagic $H$. glacialis migrate into the euphotic zone to feed on phytoplankton (Mauchline 1988). Accordingly, this diatom marker may be incorporated in the lipids secondarily via ingested copepods. It is not clear whether detritus material that sinks as marine snow into deeper layers is a significant dietary component for $H$. glacialis. The presence of phytoplankton markers at depth was confirmed by Graeve et al. (1997), who found diatom markers in various benthic organisms from sub-arctic waters.

\section{Digestive enzymes}

Proteins are important metabolic energy sources in many crustaceans. This has been shown for both the Antarctic krill Euphausia superba and the northern krill Meganyctiphanes norvegica (Virtue et al. 1993, Saborowski et al. 2002, Stübing et al. 2003). In the present study, northern krill exhibited significantly higher proteolytic activities than the decapod Hymenodora glacialis. This indicates that $M$. norvegica is capable of utilizing alimentary proteins much more rapidly than $H$. glacialis, which might be a consequence of the higher metabolic energy demand and energy turnover in krill.

Northern krill performs diel vertical migrations, from $\sim 100 \mathrm{~m}$ (in Scandinavian or Scottish fjords) to $>800 \mathrm{~m}$ (in the Mediterranean) (Liljebladh \& Thomasson 2001, Tarling et al. 2001). In sub-arctic waters, Meganyctiphanes norvegica is considered to be one of the most 
important vertical migrators (Roe \& Griffiths 1993). Acoustic Doppler current profiler records from the Greenland Sea showed backscattering layers ascending from 300 to $400 \mathrm{~m}$ depth at daytime to the surface at night (Heywood 1996). Extended and frequent vertical migration, however, is energy-demanding. In laboratory experiments northern krill increased respiration rates during extended swimming by $60 \%$ over routine metabolic rates (Saborowski 2004). Similar results were found in another euphausiid and some mysids (Torres \& Childress 1983, Cowles \& Childress 1988, Buskey 1998). Accordingly, elevated activities of digestive proteolytic enzymes are suitable to rapidly and efficiently utilize prey and, thus, to fuel the additional metabolic energy demands for vertical migration and the active life style in general.

Hymenodora glacialis specimens, in contrast, are considered sluggish bathypelagic non-migrators (Mauchline 1988). Therefore, they do not require additional metabolic energy for vertical migration and do not need to synthesize and maintain a vast amount of enzymes. Reduced catabolic rates due to low digestive enzyme activities can be compensated by prolonged gut retention. Many species of crustaceans and fishes, which ingest food of poor nutritive value, thus improve the assimilation of nutrients (Tirelli \& Mayzaud 2005). We assume that this applies for $H$. glacialis as well (Teschke \& Saborowski 2005). This suggestion is supported by the expression of different proteinase classes in both species.

Serine and cysteine proteinases, both representing endopeptidases with various specificities, belong to the dominant proteinase classes in crustaceans. There is some indication that the expression of serine and cysteine proteinases may be related to different systematic groups of crustaceans (Teschke \& Saborowski 2005). For instance, serine proteinases prevail in the euphausiid Euphausia superba, while cysteine proteinases dominate in the caridean shrimps Crangon crangon, C. allmani and Pandalus montagui. Our results are in accordance with these findings: inhibitor assays confirmed that serine proteinases dominated in the euphausiid $M$. norvegica, while cysteine proteinases formed the major class in the caridean decapod $H$. glacialis. The physiological implication of expressing different proteinase classes is not yet clear. However, the different enzymes may act predominantly in different compartments of the midgut gland and the digestive tract (Teschke \& Saborowski 2005).

Serine proteinases, representing trypsin- and chymotrypsin-like enzymes and brachyurins, have been identified in the digestive tract of many crustacean species. Maximum amounts were present in the stomach, where these enzymes accumulate (e.g. Saborow-ski et al. 2004). In the Antarctic krill Euphausia superba, proteolytic ac- tivity was more than 10 times higher in the stomach than in the midgut gland (Buchholz \& Saborowski 1996). Accordingly, serine proteinases are synthesized in midgut gland cells, released into the lumen and accumulated in the stomach. There, these endopeptidases are able to rapidly hydrolyse alimentary proteins as soon as food is ingested. Hydrolysed peptides and amino acids are subsequently absorbed in the midgut gland. The strategy of protein utilization in Meganyctiphanes norvegica may follow rapid extraction of nutrients by high extracellular enzyme activities, fast gut passage and rapid ability to digest newly ingested food items.

Cysteine proteinases, e.g. cathepsin L-like enzymes, are thought to act also within the cells of the midgut gland (Hu \& Leung 2004). Their more acidic activity profiles correspond better with the $\mathrm{pH}$ conditions in lysosomes. Therefore, it may be suggested that those crustaceans, which synthesize cysteine proteinases, retain these enzymes within the cell and thus perform a significant share of their digestion intracellularly $(\mathrm{Hu}$ \& Leung 2007). In this way the amount of enzymes released into the stomach can be reduced, as well as the share of active enzymes in the midgut gland. Nevertheless, the catalytic potential is maintained, because the incorporated food items are retained in the digestive organs and longer exposed to enzymatic digestion. This strategy entails longer gut transit times and probably more complete digestion and resorption of nutrients. Simultaneously, the loss of enzymes via faeces is limited and thus the metabolic demand for enzyme synthesis is reduced. However, detailed histochemical investigations are needed to support this hypothesis.

\section{CONCLUSIONS}

Despite the unavoidable snapshot nature of the present study, the results revealed differences between the euphausiid Meganyctiphanes norvegica and the decapod Hymenodora glacialis. Both species exhibit very different ecophysiological traits of food utilization and energy storage, reflecting deviating life strategies. The northern krill $M$. norvegica tends to rely on a more continuous food supply in upper water layers, owing to its high mobility. Because of its high digestive enzyme activities, it is able to utilize scarcely appearing food more efficiently than $H$. glacialis. In contrast, the sluggish bathypelagic $H$. glacialis may better cope with longer periods of starvation, due to generally much larger lipid stores. They may contribute to neutral buoyancy and thus save additional metabolic energy which is otherwise spent for locomotion. Lipid analyses as well as enzyme measurements indicate that in $M$. norvegica protein catabolism may play a more important role, while in H. glacialis lipid catabolism seems to prevail. 
Acknowledgements. We gratefully acknowledge the support of the crew of the RV 'Polarstern' and the work of our technical staff, P. Wencke, G. Sahling and N. Mühlenbeck, in lipid analyses and enzyme assays.

\section{LITERATURE CITED}

Ackman RG, Eaton CA, Sipos JC, Hooper SN, Castell JJ (1970) Lipids and fatty acids of two species of North Atlantic krill (Meganyctiphanes norvegica and Thysanoessa inermis) and their role in the aquatic food web. J Fish Res Board Can 27:513-533

> Auel H, Hagen W (2002) Mesozooplankton community structure, abundance and biomass in the central Arctic Ocean. Mar Biol 140:1013-1021

Boysen E, Buchholz F (1984) Meganyctiphanes norvegica in the Kattegat. Studies on the annual development of a pelagic population. Mar Biol 79:195-207

Bradford MM (1976) A rapid and sensitive method for the quantitation of microgram quantities of protein utilizing the principle of protein-dye binding. Anal Biochem 72: 248-254

Buchholz F, Saborowski R (1996) A field study on the physiology of digestion in the Antarctic krill, Euphausia superba, with special regard to chitinolytic enzymes. J Plankton Res 18:895-906

Buchholz F, Buchholz C, Reppin J, Fischer J (1995) Diel vertical migrations of Meganyctiphanes norvegica in the Kattegat: comparison of net catches with acoustic Doppler current profiler. Helgol Meeresunters 49:849-866

Buskey EJ (1998) Energetic cost of position-holding behavior in the planktonic mysid Mysidium columbiae. Mar Ecol Prog Ser 172:139-147

Clarke A, Holmes LJ (1986) Lipid content and composition of some midwater crustaceans from the Southern Ocean. J Exp Mar Biol Ecol 104:31-51

Codispoti LA, Friederich GE, Sakamota CM, Gordon LI (1991) Nutrient cycling and primary production in the marine systems of the Arctic and the Antarctic. J Mar Syst 2:359-384

> Cowles DL, Childress JJ (1988) Swimming speed and oxygen consumption in the bathypelagic mysid Gnathophausia ingens. Biol Bull 175:111-121

Dalsgaard J, St. John M, Kattner G, Müller-Navarra D, Hagen W (2003) Fatty acid trophic markers in the pelagic marine environment: a review. Adv Mar Biol 46:227-340

> Domanski P (1986) The near-bottom shrimp faunas (Decapoda: Natantia) at two abyssal sites in the Northeast Atlantic Ocean. Mar Biol 93:171-180

Einarsson H (1945) Euphausiacea. I. Northern Atlantic species. Dana Rep 27:1-184

Falk-Petersen S, Hopkins CCE, Sargent JR (1990) Trophic relationships in the pelagic Arctic food web. In: Barnes M, Gibson RN (eds) Proc 24 Eur Mar Biol Symp, Oban, Argyll. Aberdeen University Press, Aberdeen, p 315-333

Falk-Petersen S, Hagen W, Kattner G, Clarke A, Sargent JR (2000) Lipids, trophic relationships, and biodiversity in Arctic and Antarctic krill. Can J Fish Aquat Sci 57(Suppl 3):178-191

Fraser AJ, Tocher DR, Sargent JR (1985) Thin-layer chromatography-flame ionization detection and the quantitation of marine neutral lipids and phospholipids. J Exp Mar Biol Ecol 88:91-100

> Graeve M, Kattner G, Hagen W (1994) Herbivorous or carnivorous? On the significance of lipid compositions as trophic markers in Antarctic copepods. Deep-Sea Res I 41:915-924

Graeve M, Kattner G, Piepenburg D (1997) Lipids in Arctic benthos: Does the fatty acid and alcohol composition reflect feeding and trophic interactions? Polar Biol 18:53-61

Hagen W (2000) Lipids. In: Harris RP, Wiebe PH, Lenz J, Skjoldal HR, Huntley M (eds) ICES zooplankton methodology manual. Academic Press, San Diego, CA, p 113-119

Hagen W, Kattner G (1998) Lipid metabolism of the Antarctic euphausiid Thysanoessa macrura and its ecological implications. Limnol Oceanogr 43:1894-1901

Hagen W, Kattner G, Graeve M (1993) Calanoides acutus and Calanus propinquus, Antarctic copepods with different lipid storage modes via wax esters and triacylglycerols. Mar Ecol Prog Ser 97:135-142

> Hagen W, Kattner G, Graeve M (1995) On the lipid biochemistry of polar copepods: compositional differences in the Antarctic calanoids Euchaeta antarctica and Euchirella rostromagna. Mar Biol 123:451-457

Head EJH, Conover RJ (1983) Induction of digestive enzymes in Calanus hyperboreus. Mar Biol Lett 4:219-231

- Heywood KJ (1996) Diel vertical migration of zooplankton in the Northeast Atlantic. J Plankton Res 18:163-184

> Hirche HJ (1989) Spatial distribution of digestive enzyme activities of Calanus finmarchicus and C. hyperboreus in Fram Strait/Greenland Sea. J Plankton Res 11:431-443

Hirche HJ (1997) Life cycle of the copepod Calanus hyperboreus in the Greenland Sea. Mar Biol 128:607-618

Hirche HJ, Niehoff B (1996) Reproduction of the Arctic copepod Calanus hyperboreus in the Greenland Sea: field and laboratory observations. Polar Biol 16:209-219

Hu KJ, Leung PC (2004) Shrimp cathepsin L encoded by an intronless gene has predominant expression in hepatopancreas, and occurs in the nucleus of oocyte. Comp Biochem Physiol 137B:21-33

Hu KJ, Leung PC (2007) Food digestion by cathepsin L and digestion-related rapid cell differentiation in shrimp hepatopancreas. Comp Biochem Physiol 146B:69-80

> Ikeda T, Dixon P (1982) Body shrinkage as a possible overwintering mechanism of the Antarctic krill, Euphausia superba Dana. J Exp Mar Biol Ecol 62:143-151

> Kaartvedt S, Larsen T, Hjelmseth K, Onsrud MSR (2002) Is the omnivorous krill Meganyctiphanes norvegica primarily a selectively feeding carnivore? Mar Ecol Prog Ser 228: 193-204

> Kattner G, Fricke HSG (1986) Simple gas-liquid chromatography method for the simultaneous determination of fatty acids and alcohols in wax esters of marine organisms. J Chromatogr A 361:263-268

Kattner G, Graeve M (1991) Wax ester composition of the dominant calanoid copepods of the Greenland Sea/Fram Strait region. In: Sakshaug E, Hopkins CCE, Øritsland NA (eds) Proc Pro Mare Symp Polar Mar Ecol, Trondheim, 12-16 May 1990. Polar Res 10:479-485

Kattner G, Hagen W (1995) Polar herbivorous copepods: different pathways in lipid biosynthesis. ICES J Mar Sci 52: 329-335

Kattner G, Hirche HJ, Krause M (1989) Spatial variability in lipid composition of calanoid copepods from the Fram Strait, the Arctic. Mar Biol 102:473-480

Lass S, Tarling GA, Virtue P, Matthews JBL, Mayzaud P, Buchholz F (2001) On the food of northern krill Meganyctiphanes norvegica in relation to its vertical distribution. Mar Ecol Prog Ser 214:177-200

> Lee RF (1974) Lipid composition of the copepod Calanus hyperboreus from the Arctic Ocean. Changes with depth and season. Mar Biol 26:313-318

Lee RF, Hagen W, Kattner G (2006) Lipid storage in marine zooplankton. Mar Ecol Prog Ser 307:273-306

Liljebladh B, Thomasson MA (2001) Krill behaviour as 
recorded by acoustic Doppler current profilers in the Gullmarsfjord. J Mar Syst 27:301-313

Mauchline J (1980) The biology of euphausiids. Adv Mar Biol $18: 373-623$

Mauchline J (1988) Growth and breeding of meso- and bathypelagic organisms of the Rockall Trough, northeastern Atlantic Ocean and evidence of seasonality. Mar Biol 98: 387-393

Mauchline J, Fischer LR (1969) The biology of euphausiids. Adv Mar Biol 7:1-454

Mayzaud P, Errhif A, Bedo A (1998) Distribution of plankton lipids and their role in the biological transformation of Antarctic primary production. J Mar Syst 17:391-410

$>$ McClatchie S (1985) Feeding behaviour in Meganyctiphanes norvegica (M. Sars) (Crustacea: Euphausiacea). J Exp Mar Biol Ecol 86:271-284

Quetin LB, Ross RM (1991) Behavioral and physiological characteristics of the Antarctic krill, Euphausia superba. Am Zool 31:49-63

Richter C (1995) Seasonal changes in the vertical distribution of mesozooplankton in the Greenland Sea Gyre $\left(75^{\circ} \mathrm{N}\right)$ : distribution strategies of calanoid copepods. ICES J Mar Sci 52:533-539

Ritterhoff J, Zauke GP (1997) Trace metals in field samples of zooplankton from the Fram Strait and the Greenland Sea. Sci Total Environ 199:255-270

Roe HSJ, Griffiths G (1993) Biological information from an acoustic Doppler current profiler. Mar Biol 115:339-346

Saborowski R (2004) Restless krill — metabolic costs in pelagic environments. Biol Mar Medit 11:206 (Abstract)

Saborowski R, Bröhl S, Tarling GA, Buchholz F (2002) Metabolic properties of Northern krill, Meganyctiphanes norvegica, from different climatic zones. I. Respiration and excretion. Mar Biol 140:547-556

Saborowski R, Sahling G, Navarete del Toro MA, Walter I, García-Carreño FL (2004) Stability and the effects of organic solvents on the endopeptidases from the gastric fluid of the marine crab Cancer pagurus. J Mol Catal Enzym 30:109-118

Saether O, Ellingsen TE, Mohr V (1986) Lipids of North Atlantic krill. J Lipid Res 27:274-285

Sameoto DD (1976) distribution of sound scattering layers caused by euphausiids and their relationship to chlorophyll a concentrations in the Gulf of St. Lawrence estuary. J Fish Res Board Can 33:681-687

Sameoto DD (1980) Relationship between stomach contents and vertical migration in Meganyctiphanes norvegica, Thysanoessa macrura and T. inermis (Crustacea, Euphausiacea). J Plankton Res 2:129-143

Sargent J, Falk-Petersen S (1981) Ecological investigation on the zooplankton community in Balsfjorden, northern Norway: lipids and fatty acids in Meganyctiphanes norvegica, Thysanoessa raschii and $T$. inermis during mid-winter. Mar Biol 62:131-137

Editorial responsibility: Hans Heinrich Janssen, Oldendorf/Luhe, Germany
Sargent JR, Whittle KJ (1981) Lipids and hydrocarbons in the marine food web. In: Longhurst AR (ed) Analysis of marine ecosystems. Academic Press, London, p 491-533

Sargent JR, Gatten RR, McIntosh R (1974) Biosynthesis of wax esters in cell-free preparations of Euchaeta norvegica. Comp Biochem Physiol 47B:217-227

Sargent JR, Gatten RR, Henderson RJ (1981) Lipid biochemistry of zooplankton from high latitudes. Oceanis 7:623-632

Spindler M, Hagen W, Stübing D (1998) Scientific cruise report of the Arctic Expedition ARK-XIII/1 of RV 'Polarstern' in 1997. Ber Polarforsch 296:1-65

Stübing D, Hagen W (2003) Fatty acid biomarker ratios: Suitable trophic indicators in Antarctic zooplankton? Polar Biol 26:774-782

Stübing D, Hagen W, Schmidt K (2003) On the use of biomarkers in marine food web analysis: an experimental case study on Antarctic krill, Euphausia superba. Limnol Oceanogr 48:1685-1700

Tarling GA, Couzin-Roudy J, Buchholz F (1999) Vertical migration behaviour in the northern krill Meganyctiphanes norvegica is influenced by moult and reproductive processes. Mar Ecol Prog Ser 190:253-262

Tarling GA, Matthews JBL, David P, Guerin O, Buchholz F (2001) The swarm dynamics of northern krill (Meganyctiphanes norvegica) and pteropods (Cavolinia inflexa) during vertical migration in the Ligurian Sea observed by an acoustic Doppler current profiler. Deep-Sea Res I 48: 1671-1686

Teschke M, Saborowski R (2005) Cysteine proteinases substitute for serine proteinases in the midgut glands of Crangon crangon and Crangon allmani (Crustacea: Caridea). J Exp Mar Biol Ecol 316:213-229

Tirelli V, Mayzaud P (2005) Relationship between functional response and gut transit time in the calanoid copepod Acartia clausi: role of food quantity and quality. J Plankton Res 27:557-568

Torres JJ, Childress JJ (1983) Relationship of oxygen consumption to swimming speed in Euphausia pacifica. 1. Effects of temperature and pressure. Mar Biol 74:79-86

Torres JJ, Donnelly J, Hopkins TL, Lancraft TM, Aarset AV, Ainley DG (1994) Proximate composition and overwintering strategies of Antarctic micronektonic Crustacea. Mar Ecol Prog Ser 113:221-232

Virtue P, Nichol S, Nichols PD (1993) Changes in the digestive gland of Euphausia superba during short-term starvation: lipid class, fatty acid and sterol content and composition. Mar Biol 117:441-448

> Wishner KF (1980) The biomass of the deep-sea benthopelagic plankton. Deep-Sea Res A 27:203-216

Yayanos AA, Benson AA, Nevenzel JC (1978) The pressurevolume-temperature (PVT) properties of a liquid mixture from a marine copepod, Calanus plumchrus: implications for buoyancy and sound scattering. Deep-Sea Res 25: $257-268$

Submitted: February 23, 2009; Accepted: June 9, 2010 Proofs received from author(s): August 19, 2010 